\title{
Martyrs and Living Martyrs of the People's War in Nepal
}

Marie Lecomte-Tilouine

\section{(2) OpenEdition}

\section{Journals}

\section{Electronic version}

URL: http://journals.openedition.org/samaj/3018

DOI: $10.4000 /$ samaj.3018

ISSN: $1960-6060$

\section{Publisher}

Association pour la recherche sur l'Asie du Sud (ARAS)

Printed version

ISBN: 1960-6060

\section{Electronic reference}

Marie Lecomte-Tilouine, « Martyrs and Living Martyrs of the People's War in Nepal », South Asia

Multidisciplinary Academic Journal [Online], 4 | 2010, Online since 17 December 2010, connection on 30 April 2019. URL : http://journals.openedition.org/samaj/3018 ; DOI : 10.4000/samaj.3018

This text was automatically generated on 30 April 2019.

\section{c.) (i)}

This work is licensed under a Creative Commons Attribution-NonCommercial-NoDerivatives 4.0 International License. 


\title{
Martyrs and Living Martyrs of the People's War in Nepal
}

\author{
Marie Lecomte-Tilouine
}

\section{Introduction}

1 In Nepal, the armed wing of the Maoist movement (PLA) grew up as a collective of martyrs-to-be, whose examples were disseminated as soon as they fell, and enticed new volunteers. Its dynamic relied on self-sacrifice rather than heroic prowess, and despite its Marxist ideology, the PLA recalls the Revolutionary Guard in $\operatorname{Iran}^{1}$ and shares similarities with suicide bombers. In both cases, recruited volunteers whose overt motives are not based on self-interest become living martyrs at the time of their engagement and from then on record their testimonies before facing death. ${ }^{2}$ During the People's war (1996-2006), these testimonies not only took the form of letters addressed to relatives, but emerged as a literary genre, providing invaluable material with which to investigate the conception of martyrdom and the question of its exemplarity. I will focus on the role it played for Nepalese Maoists and for their party during the People's war and in the period that followed the peace agreement of November 2006, but will leave aside the most recent developments in Nepalese political life, notably the emergence of a form of competition between the different political forces, vying to capitalize on the benefits of martyrdom.

2 More than the result of diffuse forces such as mimesis, ${ }^{3}$ or martyropathy (Khosrokhavar 1998), the martyr boom in Nepal rose within an organized movement, which initially had only immaterial means at its disposal. Martyrdom acquired a strong power of attraction in that it fundamentally asserts that anyone, whether illiterate, poor or of the lowest status, is of 'priceless' value, and can contribute to the magnificent project of changing the order of things by putting his or her life at stake. 


\section{History of the concept of martyrdom in Nepal}

3 To characterize the Maobadi martyrdom is an endeavour made complex by the variety of influences which contributed to its formation. Among them, is the nebulous heritage that the notion conveyed when it came to Nepal, probably in the 1940s, as the Arabic loanword shahid. Shahid, like the Greek root martur, means witness. In Arabic, the shahid is a witness of his faith or of his love. But in South Asia, the latter dimension took on secondary importance ${ }^{4}$ and the shahid's faith became a secularized sign of nationalist and political commitment, especially in the 1930s, during the struggle for independence in India, whereas it combines nationalist, political and religious dimensions in contexts influenced by Islam, such as Punjab or Kashmir. ${ }^{5}$ In Nepal itself, martyrdom was informed by the political events within which it emerged: first the anti-Rana movement in the 1940s, ${ }^{6}$ then the anti-Panchayat actions from the 1960s onwards, and in particular the People's Movement of 1990 (or Jana Andolan I). It thus developed in relation to struggles against central government and to demands for democracy without including any major religious or nationalistic dimension. Revolutionary China has also influenced the Nepalese (and Indian) Communists since the $1940 \mathrm{~s},{ }^{7}$ as shown by the images they use, such as the martyr's death as weightier than a mountain. ${ }^{8}$ Yet, the Maobadis' Nepalization of Mao's formula, in which Mount Tei is replaced by Mount Everest, is symptomatic of their specific construction of martyrdom, which gained momentum within an international context marked by Islamist armed movements and terrorism. In fact, in Communist China, the figure of the lieshi (martyrs) only emerged in 1949 and was therefore not operative during the war, but instead came as a response to war casualties (Sheridan 1968, Diamant 2001, Hung 2008). By contrast, with the launching of the People's war in Nepal, martyrdom immediately became a generalized phenomenon, regrouping a great variety of people and experiences in a single framework, which they contributed to inform in turn. These experiences were publicized by two weeklies (Janadesh and Janaawaj ) in poems, songs, personal accounts and extracts of diaries, many of which were written by martyrs or addressed to martyrs, in news on martyrdom and numerous tributes to martyrs written by close relatives. The Maobadis' immediate construction and use of martyrdom, simultaneous to their armed action, fits in well with their notion of 'fusion', which initially designated the fusion of urban insurrection and protracted war, but also applied to their capacity to lead war and cultural revolution at the same time, whereas these formed two distinct phases in China.

4 Despite its previous existence, it was thus not before the launching of the People's War that the concept of martyrdom acquired its full force. ${ }^{9}$ The 'boom' in martyrdom which invaded Nepal's political and cultural scene is no better underscored than by a person using the pseudonym 'Living Martyr' who, commenting on new martyrs nominated by the government with the following 'Appeal to open martyrdom Ministry', said 'Wah! Martyrs martyrs everywhere. Char jaat chattish sahid ko sajha phulbari hami! Kati ramro! Good job cabinet/government! ... We should be proud, India does not have half as many martyrs. ${ }^{10}$

5 Together with a surge in the number of martyrs, the People's War brought about a wave of Living martyrs, who survived the war and stand at the crossroads between the living and the dead, witnesses and historians. I will argue that they combine all the ingredients 
to secure immortality, while fallen immortals have already lost their individualities to play a collective and anonymous role.

\section{Self-sacrifice versus sacrifice}

6 In Nepal, martyrdom perverted the logic of legitimate violence, the conception of war and death. Whereas the alternative for the Hindu warrior was to offer sacrifices or be offered in sacrifice, the Maoist ideology put a term to reciprocity, broke the warlike symmetry, which stemmed from shared values, the same caste status of warriors, and common rules of combat. This symmetry was displayed in archetypal epic scenes of confrontation between two Kshatriya heroes, one as strong as the other, clashing in a duel subsuming the battle, sometimes to kill each other at the end in order to complete the pattern of equality. This model, though more ideal than actually enacted as such, had not been replaced by any other before the Maoists introduced the idea that they were not fighting their alter egos, but their exact opposites: 'venal royal butchers' paid to maintain autocracy and feudalism when the Maoists themselves had renounced everything for the liberation of the people and were ready to pay for it at the price of their 'priceless' lives. This upset the whole economy of war and death.

7 Yet, whereas the nature of war became fully asymmetrical, the Nepalese revolutionaries sought to restore a sense of symmetry in the form of combat, by acting in accordance with the principle of military confrontation. It is true that they sometimes made use of mines and other forms of sabotage, but they essentially remained attached to deadly faceto-face combat, and led frontal assaults against the most conspicuous strongholds of the enemy. In attacking the citadels of power with a real army, they chose to publicly display their power and the nobility of their methods, to place themselves on par with their enemy.

8 In this respect, the People's War differs from most modern movements struggling against established forces. In Nepal, the rebels never resorted to political assassinations of key political figures-unlike the Naxalites in India-or to bombing the civilian populationunlike some autonomy movements of northeast India. With the Tamil Tigers they share the fact that they have developed an effective and well-organized army, fit for large-scale action, but unlike the former who are credited with being forerunners in this field the Maobadis never organized suicidal actions. They symbolically offered themselves in sacrifice, but their actual deaths were neither deliberate nor inevitable. Far from suicidal, their actions were carefully planned and tailored to their military capabilities. Death was a possible but unintended outcome. Admittedly, it was much more probable than in times of peace and was accepted in advance as an inevitable part of action. Then, death was 'received', voluntarily, and turned them into martyrs. This ultimate end offered fighters an opportunity to transform their demise into a deed, and, in their understanding, to provide a share of the symbolic capital (the 'needed blood') necessary for the final victory of the revolution. Surya Kiran's (2003) experience as a PLA fighter illustrates this moment:

My consciousness (hos) abandoned me... I tried to break the circle [of the enemies] and looked for the weak point, but there was none. I thought that if I survived, I would let my blood flow for the revolution another time, and if I died, it would flow this time. I looked at my friends who were like a piece of my heart for the last time, and I jumped at the speed of the wind. Then bullets rained down on me. They penetrated houses; the Chure Mountains echoed the sound of rifles, forest birds 
cried... Once again the bullets rained down. The first time, they touched no part of my body, but the second time I could not remain unharmed by the continuous firing. My blood started to flow. I fell. I told myself, I should say one last time: Long live the People's War, but I refrained because I realized that in this position I was safe... I stayed silent in the bush for half an hour... and when I felt that there was nobody... I started to walk.

In the ultimate confrontation with death, martyrdom thus offered the rebel a means of salvation, and the bravado that accompanied it, in the form of his last cry, was the final burst signifying that death was not defeat, but a choice. This is thus not the same path chosen by disillusioned youngsters, who become shahid through suicide. ${ }^{11}$

PLA fighters' engagement was different from that of Maoist political activists or 'cultural warriors' because of their closer relationship with death. But all party members were likely to be killed and were recognized as martyrs by the party upon their death, sometimes even when it was accidental. The term also applied to non-committed people killed by government forces, and to those who went missing. Yet, it is obvious that some martyrs were more legitimate than others, and that the PLA fighters killed during the battle constituted the ideal-type of martyr. Their very enrolment was depicted as an initial sacrifice, following which their life was suspended, and their death was merely 'the fall of their material form'. With their death caused as it was by a 'butcher', the rebels remained the agents of their self-sacrifice. Initiated consciously, fully actualized when they 'obtained martyrdom' (shahadat prapta paunu), as something knowingly accepted, the martyrs' death deprived the opposing party of heroism in battle and its ability to offer them up in sacrifice. Conversely, with no other way out, the rebels would 'annihilate' their enemies, denying them the glorious death of the warrior by not offering them in sacrifice. A noble, voluntarily chosen death and the coveted status of martyr awaited the rebels, while the enemies were simply 'erased' or even 'cleansed' in an unprecedented movement of purification. By offering themselves in sacrifice through their commitment, Maoist soldiers became living dead, martyrs-to-be. Like the Tamil Tigers who flaunted a cyanide capsule pendant, the Maobadis wore the sign of their imminent demise on their foreheads: a mourning headband (kaphan) or a red star, which, in their movement designates a martyr rather than the unity of the workers. Detached from their 'material form' (bhautik rup), they mortified it so that violence and persecution had no effect on them, except to strengthen their determination. By this action on the self, the People's War perverted the sacrificial logic presiding over war, its bilateral structure.

The ideas, images and emotions that surrounded and defined martyrdom were expressed in an array of Maoist literature, especially poetry, which is its most exalted form (Lecomte-Tilouine 2009, chapter 8). This popular genre arose spontaneously in comrades' diaries and was disseminated through Maoist weeklies during hostilities. In this subliminal expression of war, self-sacrifice confers a kind of abstract immortality, which benefits the movement. Transformed into stars, martyrs shed light on the world plunged into the darkness of feudal and imperialist obscurantism, facilitating the progression of their comrades..$^{12}$ The starry sky formed a projection-space for revolutionary fighters, themselves wearing a red star on their foreheads, and likely to join the plethora of their immortal and celestial comrades. The martyrs also passed on their 'dreams' and entrusted their comrades with making them come true. Inhabited by the fire of fury, hungry for revenge and justice, their comrades' death drove them into an apocalyptic world of which poetry accentuates the fantasy, mixing horrifying images with a kind of joy in a broad reversal of values. 

possible to determine whether it was prompted by party leaders or merely encouraged. Parallel to the Prachandapath, it forms a meaningful, telling, and intelligible body of texts, born directly from the war and 'written with the martyrs' blood'. Sustained by frequent quotations by the Supreme Leader, a sign of its orthodoxy, popular Maoist literature primarily relies on the experience of the warrior as the ultimate form of revolutionary exemplarity. The Prachandapath played a different role: endowed with performative qualities, it was the most powerful weapon of the revolution and the substance that irrigated it. Revolutionary fighters seized upon its main concept, that of 'fusion', and applied it to areas far more fundamental even than that of the strategy proposed by their ideologue, wielding, as they say, the gun in one hand and the pen in the other, and thereby sweeping away the distinction between kshatra and brahman, i.e. action/politics versus ideology/spirituality.

Those who appropriated the Maoist revolutionary thought set it up as a vast selfsacrificial undertaking: advocating the use of violence, the party's ideology was enriched by the perception of those who engaged in action, and who reformulated the Marxist Prachandapath in a pseudo-religious vocabulary obsessed with martyrdom, as the only way to undermine the government and put an end to oppression and exploitation. The transformation of the world by the People's War was to take effect on the individual, the government, and ultimately society. The primary beneficiaries of its power of transformation were, quite logically, the combatants of the armed wing, and especially its weakest members, including women and Dalits. ${ }^{13}$ Despite a hierarchy deemed necessary for the 'organization', they found equality within its ranks, in part because of the Maoist egalitarian ideology, but also because each of them was equally likely to offer their life and become a martyr. Numerous combatants highlighted the fact that with a gun in their hands there was no longer any difference between high and low, rich and poor, men and women. They converged on this point with the Girardian idea of a violent collective which erases differences, but formulated it in a more convincing manner, emphasizing that everyone can handle modern weaponry with the same dexterity, thereby cancelling out not only social distinctions, but also physical differences. ${ }^{14}$

Beyond the weapons which endowed each and everyone with the same destructive power, in the PLA, everyone was identical in that they shared the same ideas, especially a same conception of death as an inevitable event that must not be feared but taken advantage of. In Maoist terms, this idea differentiated 'those who have understood' from others. It was scrutinized in Maoist newspapers, either in slightly clumsy and abstract texts born from 'Scientific Thought', or in enthusiast poetry, as the two extracts below respectively illustrate:

How could we change the world without understanding the meaning of social and natural life and of death? How could we recognize the meaning of life and death without dialectics? Dialectics make those who died in the red history survive for centuries. Thousands of immortal persons sacrificed in the war of liberation, in conquering death thanks to the proletarian thought that understood death, have left an eternal will. They have left a teaching: that we have to see victory in thousands of defeats (Vidhanakumar 2003).

Sacrifice / They are impatient to go to the front, / because they know that death in war is not death, / it's the bloody seed from which golden communism will grow... / Now, I start to see a priceless life in my death.../ Because I understood, yes in truth, that it will be a priceless sacrifice for Communism (Sushil 2005).

South Asia Multidisciplinary Academic Journal, 4 | 2010 

also constantly put this forward. Thus, when I asked Pavan what the reason was for their victory, he answered: 'Being a soldier in the Royal Army is a profession like any other, it's for money. We, we were not paid, we undertook to liberate the country and were ready to die for it, to pay with our blood'. Pavan took part in all major attacks in western Nepal from 2002 onwards, while his brother was a soldier in the Royal Army; he thus knows the two camps well. His evocation of the strength of conviction and sacrifice signed his affiliation to the Maoist party, but it is clearly a personal statement too.

to "pay' with his/her blood instead of being paid to kill, the martyr was qualified as 'heroic' (bir shahid). In this manner, s/he literally absorbed the hero, and the shift from one figure to another captures the transformation of war observable within the People's War. Epic heroes, both in great pan-Hindu epics and in heroic ballads of western Nepal, are superheroes endowed with qualities beyond those of ordinary humans: they are stronger, taller, more skilful or cunning. Thus, to take the most famous of them, Bhimsen is a colossus, and his brother Arjun, the most skilled among archers. The hero fights for his camp more than for a cause, and challenges another hero, his alter ego. His victory is uncertain faced with that other superman displaying the same qualities. The heroic martyr of the People's War, by contrast, has no particular talent. Whether a man or a woman, the heroic martyr is weak. They describe themselves as poor and poorly armed. Only the cause they have adopted and the collective they have joined confer superiority on them. The martyrs can win while losing, because their deaths contribute to the final victory of the revolution by bringing energy to their comrades, and by enticing their relatives to pursue the struggle. Their victory is thus fully dependent on others, to whom they address messages in the form of poems, songs or diaries, and particularly on their comrades, without whom the circumstances of their deaths would remain unknown, and they would merely perish anonymously.

The revolutionary soldiers saw the success of their struggle as a victory of the vanquished, bolstered only by their resolution to risk their lives. They were therefore taken by Abhimanyu, the tragic hero of the Mahabharata who decided to break the circle of enemies, knowing he could not come out alive. The episode is fundamental in that it is said to mark the end of the order governed by war rules and the beginning of the Dark Age in which we live. Indeed, the enemies all united against the young man instead of challenging him in a duel one after another, as was the rule. It is remarkable that the breaking of Hindu laws of war was operated by self-sacrifice and that, longing for another change, Maoist warriors adopted the same method, and saw in this episode an image of their own struggle. They do not sing the prowess of the hero or heroine, but consider that their death is a victory, in being deliberately chosen in accordance with their ideals:

By the supremacy of self-sacrifice, / They were vanquished, you were victorious. / By the drop of your blood which flowed, / By your convictions, your ideals, / By the lacerations of your wounds (Shashikiran 2005).

The poet evokes three elements: self-sacrifice, belief, and brutal killing, which contribute to the definition of the revolutionary martyr, even if they are not all necessary. Only the fighter or the activist killed by the enemy combines these three dimensions and forms the most revered figure, though ordinary people killed by government forces or party members who die a natural or accidental death are also seen as martyrs. By their brutal death, the former receive a kind of bloody baptism expressing the revolutionary cause, while the latter are killed while fully committed to it. ${ }^{15}$

South Asia Multidisciplinary Academic Journal, 4 | 2010 

escapes the rules that constrain ordinary humans by the ability to embrace death during his/her lifetime. They voluntarily immerse themselves in a kind of antechamber of the afterlife, which, in poetical works, is described as an initiatory passage. There, the selfsacrificial warrior appropriates the forces of coercion by metaphorically applying fire, blood and chains to their own bodies. Through mortification, they subtract themselves from the ultimate sovereign power, the power of death, and thereby deprive the governing forces of their substance: they turn them into counter-productive power, which not only has no more control over their selves, but also contributes to strengthening that against which they are fighting. world, which is reminiscent of renouncing. Like a renouncer, PLA fighters rid themselves (tyag garna) of any comfort, of their selfishness, their families, and even their own 'material forms'. Like one who renounces, they are inhabited by fire, the fire of rage that consumes them from within and purifies them. Revolutionary commitment is also depicted as an offering on the fire altar of the revolution (krantiko vedima hominu), and as a blood sacrifice (bali dan), in such a way that it mixes all the available sacrificial registers. Whether burnt within, offered to fire, or bled white, warriors offer themselves in sacrifice while they are still alive, and well before any armed action. This reverses their values: sorrow becomes happiness and death the greatest achievement, beautiful and desirable in the form of the martyrdom that brings glory and eternity. ${ }^{16}$ On the other hand, fighters sometimes expressed anguish on their way to the battlefield, where the embodiment of their fate accompanied them in the form of the 'volunteers' ready to carry off the victims, the medical station prepared to accommodate them, and even the mass grave dug before the outset of the attack. But rather than their own death, they feared that of their comrades and the uncertainty about who was going to die. There, the alter ego's martyrdom leads to a state in which thinking about one's own death becomes possible, as Balcan, Brigade commander in the PLA, expressed: 'I've lost many friends: two died on my lap while I was looking at them. I tried to save them; I heard their blood running. I still see them ... When comrades offered themselves in sacrifice, we told ourselves: 'if they can die, why can't we? It gave us energy, mental strength'. ${ }^{17}$

21 Martyrdom clearly upsets Jankélévitch's (1966) definition of death as something unthinkable in the first person, but admissible in the second. PLA soldiers accepted their own death, but could not cope with that of their alter egos, and simply imagining it induced a sorrow that mixed in with their joy, in such a manner that they were constantly in a paradoxical state, where they needed to reconcile the extremes. Their lives were ruled by 'dialectics', which came to express every aspect of the People's War, from its ideology to each of its participant's feelings. ${ }^{18}$

ind of 'Thought' provided Maoist fighters the necessary strength to cope with their weaknesses and to transform their sadness into fury to win the battle. It even allowed them to turn the conditions of action for their benefit: generally described as initially unfair to them, either because it rained, snowed, because the night was dark or too bright, the revolutionaries' task was to 'turn the obstacle into an asset' (anukul pratikulma badalne) as the saying goes. The Thought, their all-powerful weapon, is ideal and eternal. As a kind of Atman, the ultimate reality which also constitutes the self for the Hindus, it is both integrated and remains exterior: nothing can affect it. It resides in the immaterial and immortal part of each revolutionary, which survives death. The enemies they fight 
are also as abstract as their Thought: it is feudalism, imperialism, and injustice. These are sometimes confused with the agents maintaining them, leading the police and army to be portrayed as evil beings, especially in poetry. But in battle accounts, they are usually treated as people 'who have not understood', and to whom commanders offer the possibility of surrendering shortly after the start of hostilities, and then subject them to training classes in order to transform their ideas.

Martyrs also survive through their spilled blood, which, as the blood of the demon Raktabija, is a life-giving blood: it forms blood seeds (raktabij) giving birth to a hundred New Warriors. ${ }^{19}$ Blood, once impure, acquired a sacred value. It irrigates the motherland and causes the revolution to blossom; it strengthens the soil and forms bloody foundations (ragatko Jag) for revolutionary buildings. It is also with martyrs' blood that history is written, and even poetry, hence the special status that the party conferred on their texts, which formed real messages between the immaterial immortals and those whose material form had not yet fallen.

The birth of the soldier from the martyred body was not only an image, it was also ritualized. The new recruit literally incorporated the martyr's bodily substance by marking his/her forehead with his/her blood, or red powder. The generative power of the martyr's sacrifice has numerous resonances in the Hindu world. As the martyr is not quite dead, and immediately generates a hundred other selves, there is no ritual to transform him/her into an ancestor. Their death does not pollute their families, an old Hindu rule that already applied to death in war. ${ }^{20}$ Yet, war was traditionally initiated by the symbolic killing of the enemy and the celebration of victory, whereas the Maoists commemorated their martyrs before fighting and displayed the signs of their possible death. Somehow, they thus celebrated their forthcoming defeat, but insofar as it would finally bring victory. In this manner, they changed the rules of the game by playing losertakes-all. Consistent with this rule, they acknowledged only martyrs as war heroes, while no ceremony, medal or distinction rewarded the surviving fighters. They remained a collective made up of brigades, battalions, and abstract noms de guerre until martyrdom personified them individually. They would then recover their true names, that of their parents, of their villages and the link between their previous life and their 'life in the party'. Only then would their courage, art and skill be lauded.

Fame, which forms an essential aspect of the martyr's immortality, also finds resonances in local epics. Like the hero of western Nepal's ballads, whose name 'crosses the four ages', the names of those who adopted the revolutionary cause and died for it were said to be 'carved' or 'inscribed in golden letters' in the pages of History. The meaning of death thus became secondary to commitment, which gave access to immortality, whereas ordinary Hindu dead are meant to disappear. ${ }^{21}$ The martyr's immortality was thus frequently presented as a 'victory over death'.

In the heat of war, the party ensured the martyrs' publicity by establishing their name rolls and their annual commemorations on the day the first of them fell, and by organizing numerous ceremonies, tributes, associations of martyrs' families, minutes of silence during their meetings and even immediately prior to attacks. In a less formal manner, on their way to the battle, PLA fighters often learned the news of some of their comrades' martyrdom, and some military units or attacks bore the names of martyrs. Undoubtedly, the party instrumentalized martyrdom, but it is also obvious that the fighters themselves saw it as a prestigious transformation and took steps for their lasting memory, ensuring that elements were left to sustain their future immortality after they 
had gone. In addition to the large amount of writings they produced, often just before an attack, they frequently had their picture taken, as I noted flipping through the album of a 'cultural warrior' in Rolpa, which contained a large number of photographs of people whom he introduced to me as martyrs. He and his comrades had taken the habit of photographing each other prior to any action, in case they did not come back, in order to 'make their name' (nau banaune). Comrades also ensured each other's posterity by mutually writing tributes.

\section{Saral Sahayatri, writer and commander} son of a family of nine children, he entered into politics at the age of 10 and joined the PLA at the age of 18, in 1999. He took part in many operations, always carrying with him a notebook in which he wrote poems, tributes and stories whenever he could. When he was sent to the front, he confided his precious notebook to some comrades for them to keep it in a safe place, ensuring the preservation of his work if he himself were to disappear.

This personal information is supplied in the preface of his Stories of the Revolution (Krantika kathaharu) before Saral himself addresses the reader:

I thought it would be instructive to explain how I wrote these stories. One day, Comrade Kavita [Poetry], our section commander, asked me, 'Sushil (at that time my name was Sushil), if I became a martyr, what would you write about me?' I hesitated a moment and answered: 'And you, if I became a martyr, what would you write?' She gave a small laugh and her answer has remained etched in my memory: 'My name is Poetry, so I would write a beautiful poem about you'. And I told her then: 'I would also write a nice story in memory of you'. I could not become the source of inspiration to Kavita for a beautiful poem, but she became a martyr on the Rumjatar front and I immediately composed a text in her memory. I had only been wounded, and I wrote part of this text while my friends were carrying me on a stretcher through the mountains. Before that, I had already written a few lines, but no stories (Sahayatri 2008).

The scene is instructive. It reveals the desire for immortality through a written tribute shared by both fighters. It also shows that if death in battle turns revolutionary warriors into martyrs, only their friends can compose the text that narrates their death and provides the posthumous glory to which all aspire. This necessity makes them not only warriors but also potential writers, who may one day have to fulfil the duty to keep alive the memory of those who offer their bodies to 'carve their names in history'. It was in doing his duty as quickly and heroically as possible that Saral became an author, writing his first story on a stretcher for his martyred comrade. In this case, the request and the promise of assistance in the quest for immortality are reciprocal and openly expressed, highlighting a widespread phenomenon in the Nepalese People's War. In this context, it was not a question of one or two martyrs, whose memory would be preserved by national and international media, but of thousands of people joining in the action. Only the direct witnesses, i.e. the fighters themselves, could turn into History the facts and figures of this collective quest for immortality through martyrdom.

31

Saral says that he wrote many texts during the war, most of which have been lost, burnt by the enemy or abandoned to rot in some place where he could not return. This loss is painful to him and makes him think of the many other texts that have been lost in the war. He sees this as a necessary sacrifice, similar to that of human lives: 'Today, it seems 
to me that as the sacrifice of hundreds and thousands of soldiers is necessary for the revolution to advance a step, hundreds of creations must be sacrificed for the creation of a single soldier to survive' (Sahayatri 2008). His collection is one of those surviving creations, whose value resides in all those it testifies to.

Like the surviving creations, the surviving soldiers or 'living martyrs' played a central role. The term 'living martyrs' originally applied to Brahman political opponents sentenced to death by the government but not executed because of their caste status (unlike their friends) (Fisher 1999). Within the People's War it was extended to unaccounted combatants declared martyrs but then reappeared and was applied, metaphorically, to all combatants of the PLA whose lives were sacrificed for the revolutionary cause.

The living martyrs of the first category have exercised a real power of fascination, for they literally embodied the immortality ascribed to martyrs, the reality of their presence, normally consisting of images that haunt their comrades forever. We are also tempted to see in their status an effect of the performative nature of the ceremony to declare them martyrs, the fact that ritual reality prevails over physical reality, because it transforms it. In Nepal, a person whose funerary rituals have been carried out by his family is traditionally considered dead to the latter and cannot come back or, at least, has to undergo a ceremony of rebirth. In the same way, a declared martyr who reappears is dream-like, and his testimony is endowed with a certain transcendence.

Since their establishment in UN monitored camps at the end of 2006, numerous PLA soldiers have written their life stories, focusing on their participation in the People's War. Several among them had never written anything before that, like Pavan whom I talked to in March 2009 while he was on leave in northern Gulmi and busy writing his life story. The construction of Nepalese history by its own heroes is thus ongoing and may paint a different picture in the years to come. But some of the war accounts already published by PLA soldiers will probably remain in the annals, such as Comrade Ajayashakti's Andhisang khelda (i.e. Playing with the torment) (Ajayashakti 2009), arguably one of the most captivating. This autobiography of a Living martyr as Sarul Pun Magar (alias Invincible Power) is presented on the cover, offers particularly rich anthropological material in that the author enrolled early in the Maoist armed wing, was born into a poor family that lived in a remote region and belonged to the barely literate Magar ethnic group.

\section{The story of Sarul, a living martyr}

Sarul has never been to school and he views his own literary work as one of the achievements of the revolution: 'The Nepalese revolution brought many things. It made those who didn't write write. It made those who didn't read read.... It forced me to write'. ${ }^{22}$ Sarul was born around 1978-79, and his village of Maikot in Rukum district was then ruled by the hereditary chief of Hukam: 'Dev Gharti ruled over this region, nobody broke a twig without his permission. People could not do their own work before finishing all the work in his house'. His son Uddhaman succeeded Dev, and led a long crusade about the boundaries between the villages of Hukam and Maikot, creating two factions: the power holder and his supporters in Hukam, their opponents in Maikot, all members of the same Magar group, like Sarul. Things turned sour in 1987 when Uddhaman entered Maikot to head a procession of about twenty policemen, prompting a general fight. Armed with a large stick, he broke jars of alcohol and seized chickens (without the author mentioning 
the reason for his anger). He then became the incarnation of evil in Maikot: 'For us children, Uddhaman was a demon, bhut... and we played at being Uddhaman and others, the villagers'.

It is thus around a negative exemplary figure that a climate of revolt initially emerged in this village, which later became a bastion of the revolution. Uddhaman is a concentrated mixture of authority, abuse and violence, and is backed by the government in his ability to mobilize the police for personal reasons. At least this was young Sarul's perception. With the advent of multiparty politics in 1990, the local conflict naturally took on a political hue, and when the villagers learned the news of the abolition of the Panchayat system in April 1990, they understood it as a victory over Uddhaman: 'My uncle came and told us that supporters of the partyless regime had lost and that the multiparty had won, and that we should no longer be afraid of Uddhaman'. The men of the Panchayat then rallied to the Congress party and won the 1991 election: 'In our village, they said that Uddhaman's party won, that we lost'.

The Congress now subsumed evil and Uddhaman's opponents joined the party opposing their enemy's party: the Maoists. A conflict then took hold in the village, which Sarul, like many other Maoists in the base region, calls the 'class struggle'. Uddhaman is then said to kill cows to accuse his Maoist opponents of cow-slaughter and to try to have them imprisoned on those grounds. Up to this point in the story, only Uddhaman is active. The first 'violence in return' occurred in October 1994 when thirty villagers seized Uddhaman's son and beat him up. A week later, a police operation was launched from the District Headquarters, but this time, three to four hundred villagers awaited the police and threw stones and logs at them.

By contrast with the terrorizing police raids led by the Congress, the Maoists started operations 'at the service of the people': in February 1995 a group came to Maikot to repair roads, shelters and fountains, and Sarul joined them. Another group came to dance and sing in October 1995 during the Sija Operation, and Sarul joined them again. He started to dream of becoming a gurilla (guerrilla), which in his village implied a superman with magical powers: 'A gurilla kills hundreds of people. He can even fly from one mountain to another. He can fight by hiding in a tiny crack or under a leaf... I was amazed... It made me sprout wings: if I too could follow the gurilla training, I would hit this bastard Uddhaman and the police'. Sarul learned that he would first have to work 10 or 12 years for the party to gain its trust before starting his training, yet in the winter of 1995, his decision was made, he would be a gurilla.

Sarul's depiction of the situation in Maikot during the years preceding the People's war is consistent with several other accounts. In the districts of Rolpa and Rukum, which became the Base Region, village conflicts took on a national dimension when they were transcribed in partisan terms and the police became involved in them. In the context of Maikot, Uddhaman is a real metonym of power, which probably helped to forge the idea that it was possible to fight the government with a small organization, by punishing and driving away its representatives.

From mid-December 1995, Maikot villagers prepared the People's War by gathering their guns, 200 in total, and grinding pounds of powder. Their primary purpose was to 'attack Uddhaman and the police', as his maternal uncle told Sarul. But the conflict was probably no longer a mere wrangling about cows and boundaries, since among the village 'leaders' mentioned by Sarul two were accused of Ganesh Shah's murder, a member of the 
Congress and of the Rukum District Development Committee. Two days before the official launching of the People's War, Sarul's uncle returned to Maikot to establish a 'protection organization', which included 10 to 57 people per ward, placed under the command of a chief, and Sarul became a member. They received instruction to stand guard armed with large sticks. On February 13, 1996, Maikot celebrated the official launching of the People's War, with cries of 'Long live the People's War! Down with the reactionary regime! Immortality to the martyrs!' From then on: 'It was the beginning of a new life: the days when we slept under warm blankets, and ate until our bellies were full were over, the days had arrived when we slept, starving, in caves, rock shelters and under trees'.

The villagers greeted the news of the first killing by guerrillas of police officers with dances of joy and they felt avenged. Sarul learned that the heroes of this operation were hidden in a nearby cave and his 'spirit was elated at the prospect of finally seeing the gurillas'. But he who expected to find supermen was very surprised to discover that he knew most of them. His desire to join them increased, even if he was yet again told: 'to be a gurilla you shouldn't be afraid to die, you must be brave and be able to do anything'. In the end, Sarul did not follow the training he dreamed of, but was gradually integrated. His first armed action consisted in infiltrating 'white areas' and keeping guard outside houses armed with a rifle, while his comrades spread propaganda inside. When the first comrades fell as martyrs, the link uniting them tightened: 'We parted by shaking hands and vowing to each other to fight until the final victory, even if one was to die on the battlefield'. Sarul was sent to the west to conduct operations against 'feudals'. Then, the Special Task Force was created in 1997 to fight against the elections boycotted by the Party. It was still very limited in size: three platoons in all, and the Rukum platoon that Sarul was part of, included only 21 people. In September 1999, his unit was dispatched to attack the police station in Mahat, full of enthusiasm after listening to their commander's speech and 'the heart warmed at the idea of reducing the enemy to ashes. People and activists wished us success for the operation, waving red handkerchiefs. As for our comrades, they said: 'This time tomorrow either we will be victorious or we will be martyrs'.' (Ajayashakti 2009: 19). Their success was greater than expected: they captured a high-ranking police officer, and gained much confidence.

A few months later, in February 2000, Sarul had his first direct experience with martyrdom. En route to attack the police station in Gharti gaun, his section commander Sangkalpa was joking about the stretcher they were carrying, saying that the luckiest among them would sleep on it, and this made the group laugh. The action was successful: 'encouraged by the villagers, who danced, sung and marched with torches', the rebels killed 17 policemen and wounded 18, seized about 50 weapons and a lot of ammunition. But Sangkalpa was seriously wounded and lay on the very stretcher he had joked about. Sarul was very impressed; he mused: 'Who will be a martyr? Who will be wounded? These things are hidden in the entrails of the battlefield'. He and his comrades buried Sangkalpa in the sand, 'mourning his death while laughing at the victory' (Ajayashakti 2009: 21).

In Sarul's understanding, this commando raid was 'the beginning of the police's defeat', with the latter withdrawing from most villages to join the district headquarters. 'Once the police left the villages, we began to establish people's governments' (Ajayashakti 2009: 22). Only five police outposts still stood in Rolpa and four in Rukum, which their neighbours encouraged the rebels to attack. But the party had other ambitions and decided to target a district headquarters. The choice fell on Dunai, the chief town of Dolpa district, and the preparations for its attack were held in Maikot, where the entire 
population was instructed to supply the PLA. Biding their time, the guerrillas were asked to participate in farm work to help the villagers:

The people were surprised to see us work with our weapons on us. They asked us: 'Why don't you put them down for a moment, aren't we like your family?' And we answered: 'We left our families, our property and have renounced everything for society. These are the weapons that will transform society, and they are as dear to us as our relatives' (Ajayashakti 2009: 28).

It is clear from this anecdote, as well as from Sarul's altercations with his father about his commitment, that the comrades' solidarity had become so strong by then that it separated them from their original communities. choosing to focus on his retreat, or another account of martyrdom. 'Brother, leave me here and run away. It's a thousand times better that you survive rather than die for me', says the wounded Sakunta to Sarul, who carried him on his back while the enemy surrounded them. But Sarul was not willing to obey and obtained the assistance of another comrade. They relayed each other to carry Sakunta while the other covered them, all night long, showing the strength of mutual assistance among guerrillas. Sakunta was very ill, he desperately wanted to drink and his comrades who had risked their lives to save him from the battlefield were heartbroken at not being able to bring him any relief. Sakunta died and Sarul still regrets having failed to save him: he could have made him drink his urine, or attempted to stop his bleeding, he says.

Sarul participated in several other attacks, on Kotbamga (Kalikot) or Rukumkot. 'Without us realizing it, seconds, minutes, hours, days, months and years went by'. In October 2001, he was sent to the east in order to strengthen the insurgency there, and took leave from his friends with these words: 'If we survive, we will meet again on the battlefield, if we die, we'll be known as martyrs' (Ajayashakti 2009: 38). He then undertook a long journey which reminded him of the Long March, and during the difficult climb, he recalled his sacrifice for the welfare of society, his victory over death.

Then Sarul took part in the attack on Salleri, and once again he does not dwell on the engagement itself, but on his bitter retreat. This time, it is he and one of his friends who are shot. His companion dies on the spot but some comrades manage to carry Sarul up to the forest to prevent him from being fired at. Sarul is laid in a clearing and sees his body as a red rhododendron flower, a symbol of revolution. He hears his comrades wondering whether or not he will survive, and one of them saying, 'He's going to receive martyrdom, for sure'. Sarul protests and they make a stretcher out of a blanket to carry him. They reach a ridge where, exhausted and dying of hunger, they leave two of their number to watch over him and promise to come back the next day at 8:00 to take him. Sarul tries to cope with his terrible pain by thinking of the Chinese novel Camkila rato tara ${ }^{23}$ in which the hero's father suffers serious injuries without uttering a sound (Ajayashakti 2009: 42). But he ends up passing out, and when he recovers his senses, he realizes that his two companions have disappeared, leaving him two biscuits and a bottle of water. Sarul is incredulous: 'A comrade can't abandon another comrade like that', and he convinces himself that they are going to come back. He spends some time hovering between hope and resignation, thinking that his 'sacrifice is imminent'. Night falls and 'those stars that fight the darkness encourage [him] to struggle against death' (Ajayashakti 2009: 46). When he wakes at dawn 'shaking like a shaman', the hope of seeing his comrades helps him to hold on. But time passes and no one comes; the sun rises and a terrible thirst 
seizes him. The forest and surrounding peaks turn red, then black, Sarul slumps, and 'his breath' leaves him. He still has the instinct to urinate in his bottle and drink, and then falls unconscious. When he wakes up, 'his breath restored by the urine', he continues to sink into unconsciousness and emerges intermittently, but his hope of living grows, and with it, he is seized with anguish and starts to weep.

When my comrades were martyred, my heart was broken, my mind blacked out, but I did not cry like that. I knew that the revolution cannot take place without casualties, but the fact that my friends had abandoned me made me suffer enormously... Me who said to my comrades when we were surrounded by the enemy on the battlefield, 'Friends, break the circle, save your life, don't sacrifice yourselves for me if not necessary', why did they abandon me in this state in such a safe place away from the enemy? Rather than abandoning me, it would have been much gentler to kill me with a bullet. And with these thoughts in mind, for a very long time, I poured out all the tears in my body (Ajayashakti 2009: 47).

Sarul hears a dog barking in the distance and starts crawling in that direction. He ends up reaching an old man's cowshed at night, where he passes out. The old man, first terrified, takes pity on him, and hides him under a large pile of hay. Meanwhile, hundreds of policemen roam the countryside, and Sarul hears some of them questioning the old man, who lies to protect his guest. Unfortunately, the police set up camp for the night in the cowshed on the very haystack in which Sarul is hidden, forcing him to fight off sleep all night long so as not to reveal his presence by snoring. Sarul stays under the hay for six days, unable to move. His wounds become infected. The old man, concerned with the smell that might reveal his presence, decides to take him somewhere else. He and his son carry him up to a monk's dwelling in the middle of the night. There, Sarul is offered alcohol, which soothes his pain, and allows him to sleep at last. His health improves; he manages to get some medicines and extracts three bullets lodged in his body using a blade. After spending ten days at the monk's dwelling, not knowing where to go, Sarul sets off on the road again and undertakes a painful and agonizing journey in the hope of joining his party. Betrayed by the state he is in, people fear to help him and even the parents of one of his comrades refuse to offer him shelter. He finally succeeds in contacting his party by phone and his reunion with his comrades is the source of intense emotion because Sarul was declared dead and his martyrdom ceremony had already been celebrated. Comrade Kumar, feeling 'like in a dream', tells him: 'We have had 14 martyrs at Salleri, 15 with you, but you've come back as a living martyr'. While Kumar lists the names of their martyred comrades, Sarul sees them: 'One after another, they came dancing before my eyes'.

Sarul grew up during the first years of the Maoist movement in a village struggling against an authoritative headman whom they tried to defeat by joining the opposition party. With the launching of the People's War and his enrolment as a gurilla, Sarul is sent to various places and for different military actions, which he mostly evokes by describing his experiences of retreating with the wounded, his assistance to them and his painful helplessness once out of danger. When he is sent to eastern Nepal his experience is diametrically different: he is now the wounded one, and though his state is not desperate, and the place he has reached is safe, his comrades abandon him. He owes his life to ordinary people (an old herder, a Buddhist monk, and a young girl), who, by their mere humanity, prove more courageous than his co-fighters, though Sarul never formulates this, nor seeks to denounce their behaviour. He is simply the victim of human weakness and finds the strength to surpass it and to fight death thanks to the resources he had 
acquired as a revolutionary: a model taken from a Chinese novel, and images from Maoist poetry.

Written partly in prison where Sarul spent several months ${ }^{24}$ soon after having met his friends, Playing with the torment is a witness account. A 'pacified' text like this, free of emphasis and warlike exaltation, makes use of a quite different tone from the narratives written during the heat of the action, even those signed by the same author. ${ }^{25} \mathrm{~A}$ clear-cut style and a kind of simplicity contribute to making Sarul's story a particularly touching narrative. Like him, numerous fighters have taken up writing, indignant that they had been misappropriated and their feelings and experiences betrayed by writers who never 'made anything tremble but their table' ${ }^{26}$ As I was told by Balcan, a poet and Brigade commander in the PLA, ${ }^{27}$ 'We're the main characters of this story and we must pass it on to future generations ourselves'. Those who took part in the People's War consider that they actually transformed society, and caused the monarchy's downfall. They see their struggle as unprecedented, and the subject of future history books, if not of mythology. Balcan continues:

I believe that we have accomplished historical work, that's what is important. What we have achieved, our fathers and grandfathers could not even have imagined it. The dream we had, we made it come true for future generations, and when we disappear it will be kept on paper. Me, in my life, I've handled the gun and the pen: both are rebellious (bidrohi), and I'm formulating [my experiences] in literature... Only others can write about those who handle the gun, or else we need to write it ourselves... Since we're the real characters in this story: why not write it down?... Our story is true and our literature, written in a rough (rukho) style, is realistic: we don't know how to embellish our text, how to 'make it into a circle' these things 'shot by the gun', and how to make them beautiful.

51 While numerous fighters are now busy recording their past experiences, which, in Balcan's terms, form 'a treasured literature', others are bitter, could never envisage turning to writing, and long to take up arms again.

\section{We should have gone on fighting for another ten years}

Among those who feel left out and wish to continue the fight, the young Uma is still 'ready to die', though she was initially abducted and made to join the PLA at the age of 12 . She shared her experience with me in March 2010:

They [the Maoists] took me from school. My brother was a policeman and they said he's resigning, but my brother didn't want to, so they took me away... At my first battle, I was frightened, and then, I was no longer afraid: there was nothing else to do except kill or die... In our group of seven, only two of us survived... My friend and neighbour, Krishna Gurung, ${ }^{28}$ who went off with me, was killed... Even when it's someone we don't know, we suffer, so when it's a neighbour ... Victory seemed bitter to me, but what could I do? I couldn't follow him where he went. Whether he was buried or thrown away, I don't know... We had to carry the wounded for four or five hours. We left behind those of our friends who wouldn't survive: we couldn't take them, we also had bags to carry. We looked to see who would survive. We dug a grave deep like this, in case we died, but jackals and dogs would dig them out afterwards... I wanted to do more even if I had to become a martyr, I didn't want to leave. Later, I asked myself what's the use of fighting. It is us who are fighting, it is us who are dying: the leaders, they don't die... I didn't mind dying, but I didn't want my friends to die.

When I asked her 'And you yourself, did you kill anyone?' she replied: 
I don't know. In wartime, we can even kill our friends. We played in the fire and smoke, and we didn't know who we were killing. I don't know who I shot, but I killed a person with a knife. It was a real bastard who stole, raped girls, that sort of a guy. We killed him seven times, that is to say he was warned seven times... For us in the People's Liberation Army, the policy was 'kill, cut, strike', whereas the activists, they knew a lot. At first I didn't know anything, then I realized that we were fighting to make the rich and poor equal, but that isn't likely to happen!... The only time journalists have spoken about me, was to announce my death. It was in Bagsila: in fact, I was not even hurt, I had just passed out, but the army did nothing to me, convinced that I was dead. Then they published my picture in Kantipur and you can see me lying like that. And when my friends came to take my body, I was perched in a tree, watching them... One night, we slept in a cave; I was wounded and couldn't sleep. A jackal howled and then bit my leg, maybe he wanted a taste of me, thinking I was dead... We should have gone on fighting for another ten years. organization. She endorses it and sees herself as a righter of wrong: she threw a brick at her teacher's head because he baited her, she made the party seize her father's property because he left her, she beheaded a 'son of a bitch' who mistreated women after they complained to her, and she took part in the war to change a world she did not like. Whereas her childhood father figures mistreated her, she found a family in the violent collective of the PLA, made up of 'many friends who loved her'. She feels betrayed by the leaders who agreed to sign a peace agreement and put an end to her enchanted life as a free and empowered individual. Now her violence is directed against them. Uma is very practical: she never refers to her martyred comrades' glory but still wonders what happened to their dead bodies. She admits that they had to leave the desperately wounded because bags were of more use to them. She rubbed shoulders with death throughout her teenage years, and was taken for dead on several occasions, but it makes her laugh, in the same way that she laughs when she explains how technically difficult it was to behead someone or when she describes how she was tortured in jail. The day I interviewed her, along with one of her comrades, they both expressed their disappointment that all that they had achieved during the war was wasted, that so many people had died for nothing. And they looked at me half-surprised, half-amused, when I asked them: 'didn't they become immortal stars whose names are inscribed in the pages of history?' We then started a discussion on who had 'made a name for themselves', and admitted that apart from one journalist, Krishna Sen, whom fellow journalists have given a lot of media coverage, no other martyr has risen to fame.

In fact, the Maoist party was centred on its two charismatic leaders, who were active in constructing the 'concentration of the leadership' and its durability, in order to wage a war to overthrow the old regime. The leaders planned all the armed action but never exposed themselves. Viewed from this angle, martyrdom may be understood as a mere instrument. Indeed, the only way to fight a war without any material means is to rely on symbolic capital, appealing enough and destabilizing enough to generate a revolutionary mass movement. This capital relied on the notion of 'pricelessness', in both meanings of the expression, that which costs nothing and that which is highly valued, applying both to life and death, and mixing them up. As the poet quoted above says: 'I began to see a priceless life in my death'. Yet, this apocalyptic rhetoric was not backed by the construction of a pantheon of martyrs whose hagiography could have quenched the thirst

South Asia Multidisciplinary Academic Journal, 4 | 2010 
for fame. Indeed, the party chose as its symbol the first martyr who fell after the launching of the People's War. But this 14-year-old boy did not have enough charisma or accomplishments to his credit to become anything other than a kind of 'unknown martyr', representative of all the other victims.

Like him, most martyrs of the People's war are somewhat substance-less in the way they have been commemorated. Their first textual tributes were stereotyped, offering what could be qualified as short biographical data, revealing their real identities, and retracing their education and revolutionary careers: the age at which they enrolled (and sometimes the reason for doing so), the successive positions and grades they held within the party, the military operations in which they took part. The moving part of these tributes consists in the author's feelings when learning the news of his or her comrade's martyrdom, which is given a prominent place; then, they end with the affirmation of their determination to take their revenge. These texts did not expand on the lives of individual exemplary figures, but rather inculcated a feeling of anger against the government responsible for their deaths. As time has passed, collections of such tributes to martyrs have been published, but their content is no different, and the accumulation of such bio-data is no more likely to provide solace. Thus one is tempted to say that martyrdom represented a driving force in the heat of the action, by demultiplying engagements within the martyrs' close relations, but now that time has passed, one can but retrospectively note that it was a failed quest for individual fame.

On the other hand, the living martyrs of the revolution, who were not honoured during the war, are presently carving their names into the pages of history by writing their witness accounts 'in the best possible form'. They stand as a testament to the martyrs, and their words are sacrosanct, especially when they experienced near-death. The surviving warriors are the only legitimate voices, ${ }^{29}$ and are likely to remain telling examples, endowed with enough pathos and substance to inspire other political movements. This configuration is apparently not unique to Nepal, ${ }^{30}$ showing that individual immortality (in this world) is not automatically secured by self-sacrifice. Yet, the memory of these hundreds of nameless youngsters who offered their lives to build a paradise on earth will remain an example, in that they form the dramatic and moving basis from which a few figures will become historical models for the future. ${ }^{31}$

\section{BIBLIOGRAPHY}

Ajayashakti (2003) 'Dumkibas kamandodekhi Takukot redsamma', Janadesh, 12 (10), URL: http:// www.cpnm.org (www.cpnm.org is still accessible through http://www.archive.org)

Ajayashakti (2009 [2066 Vs]), Andhisang khelda, Nepal: People's Liberation Army $5^{\text {th }}$ division.

Blom, Amélie (2007) ‘Kashmiri Suicide Bombers: Martyrs of a Lost Cause', in Amélie Blom; Laetitia Bucaille \& Luis Martinez (eds.), The Enigma of Islamist Violence, London \& New York: Hurst \& Columbia University Press, pp. 71-88.

Caulagai, Lakshmi Prasad (2007 [2064 VS]), Janasenako jivan, Butwal: Janaavahana saptahik. 
Diamant, Neil J. (2001) 'Between Martyrdom and Mischief: The Political and Social Predicament of CCP War Widows and Veterans, 1949-66', in D. Lary \& S. MacKinnon (eds.), Scars of War. The Impact of Warfare on Modern China, Vancouver: UBC Press, pp. 162-88.

Fisher, James (1999) Living Martyrs, New Delhi: OUP.

Gaur, Ishwar Dayal (2008) 'Lover-martyrs in Punjabi Literature', in S. Singh \& I. D. Gaur (eds.), Popular Literature and Pre-Modern Societies in South Asia, New Delhi: Dorling Kindersley, pp. 222-38.

Gayer, Laurent (2006) 'Le 'jeu de l'amour': trajectoires sacrificielles et usages stratégiques des martyrs dans le mouvement Sikh pour le Khalistan', Cultures et conflits, 63, pp. 113-33.

Gerami, Shahin (2003) 'Mullahs, Martyrs, and Men: Conceptualizing Masculinity in the Islamic Republic of Iran', Men and Masculinities, 5, pp. 257-74.

Girard, René (1972) La violence et le sacré, Paris: Grasset.

Jankélévitch, Vladimir (1966) La mort, Paris: Flammarion.

Khosrokhavar, Farhad (1998) 'Le modèle Bassidji', Cultures et Conflits, 29-30, pp. 59-118.

Hung, Chang-tai (2008) 'The Cult of the Red Martyr: Politics of Commemoration in China', Journal of Contemporary History, 4, pp. 279-304.

Kiran, Surya (2003 [2060 VS]) 'Dusmanbat mukta bhaera ranabhumima ramna paunda', in A. Subedi (ed.), Dusmanka killaharu kabja garda, Kathmandu: Naulo bihani, pp. 51-3.

Larzillière, Pénéloppe (2003) 'Le 'martyr' palestinien, nouvelle figure d'un nationalisme en échec', in Alain Dieckhoff \& Rémy Leveau (eds.), Israéliens et Palestiniens: La guerre en partage, Paris: Balland, pp. 80-109.

Lecomte-Tilouine, Marie (2008-2009) 'What 'really' happened in Dullu', EBHR, 33-34, pp.143-70.

Lecomte-Tilouine, Marie (2009) Hindu Kingship, Ethnic Revival and Maoist Rebellion in Nepal. Collected Essays, New Delhi: Oxford University Press.

Lecomte-Tilouine, Marie (2010) 'Fighting with ideas. Maoist and popular conceptions of war in Nepal', in Laurent Gayer \& Christophe Jaffrelot (eds.), Armed Militia of South Asia: Fundamentalists, Maoists and Separatists, London \& New York: Hurst \& Columbia University Press, pp. 65-90.

Margalit, Avishai (2003) 'The Suicide Bombers', The New York Review of Books, 16 January.

Prabhakar (2005) 'Vaigyanik drishtikon ra yojana nai vijayako adhar ho', Janadesh, 14 (35), URL: http://www.cpnm.org

Prachanda (1998) 'Two Momentous Years of Revolutionary Transformation', The Worker, 4, URL: http://www.cpnm.org

Prachanda (1999) ‘Third Turbulent Year of People’s War: A General Review’, The Worker, 5, URL: http://www.cpnm.org

Prachanda (2003) 'Let's Concentrate Total Force to Raise Preparations for the (Strategic) Offensive to a New Height Through Correct handling of Contradictions', Maoist Information Bulletin , 6, URL: http://www.cpnm.org

Prachanda (2004) 'A Brief Introduction to the Policies of the CPN (M)', The Worker, 9, URL: http:// www.cpnm.org

Sahayatri, Saral (2008) Krantika kathaharu, Nepal: People's Liberation Army.

Sapana; Sacet (2007 [2064 VS]) Raktim yuddhako yatra, Nepal: R. Thapa Magar 'Dovhan' and M. Moktan publishers. 
Sharma, Dev (2003) 'Dukh nai sukh ho', Janaawaj, 1 (43), URL: http://www.cpnm.org

Sharma, Om (2005) 'Janayoddhale yasari gare Pili kyampa kabja',Janadesh, 14 (36), URL: http:// www.cpnm.org

Shashikiran (2005) 'Abhimanyulai salam', Janadesh, 14 (14), URL: http://www.cpnm.org

Sheridan, Mary (1968) ‘The Emulation of Heroes’, The China Quarterly, 33, pp. 44-72.

Shrestha, Ganga (2003) 'Pyaro mrityu', Janaawaj, 1 (43), URL: http://www.cpnm.org

Stern, Jessica (2003) Terror in the Name of God: Why Religious Militants Kill, New York: Harper Collins.

Sushil (2005), 'Balidan', Janadesh, 14 (40), URL: http://www.cpnm.org

Thapa Chal, Sobha ['Kirti'] (2007 [2064 VS]), Kathin yatrako yatri (Traveller of a difficult travel), Nepal: People's Liberation Army, $3^{\text {rd }}$ Division.

The Worker (1997) 'Strategy and Tactics of Armed Struggle in Nepal' [Document adopted by the Third Plenum of the CC of CPN (Maoist) in March 1995], 3, URL: http://www.cpnm.org

The Worker (2004) ‘Glorious Eight Years', 9, URL: http://www.cpnm.org

Vidhanakumar (2003) ‘Gokule brihat morca ra ka. Vivekko nirnayak ladai’, Janaawaj, 1 (52), URL: http://www.cpnm.org

Whelpton, John (2005) A History of Nepal, Cambridge: Cambridge University Press.

\section{NOTES}

1. A guard who 'acquired more power and eventually subsumed the regular army', see Gerami (2003: 267).

2. On suicide bombers, see Stern (2003: 51) and Margalit (2003).

3. Which lies at the origin of collective violence for Girard (1972).

4. As shown by Gaur (2008), the lover-martyrs of Punjabi literature are now marginalized. These legendary figures refuse the patriarchal normative code, and 'de-construct the single narrative of martyrdom which historians have draped in a communitarian ambience'. Yet, the dimension is still found in the 'love' or 'passion' for martyrdom expressed in various Shi'ite contexts. On some aspects of the Sikh martyrs' love, see Gayer (2006).

5. However, most political movements using the martyrdom idiom, which is closely related to sacrifice, share formal analogies with religious organizations.

6. The Nepalese proto-martyrs are the Praja Parishad activists executed in 1941 on Juddha Shamsher Rana's order (Whelpton 2005: 67). More recently, the status of First martyr was conferred to Lakhan Thapa, who was executed in 1877 by the first Rana Prime minister, Jang Bahadur Rana (Lecomte-Tilouine 2009).

7. The Nepalese and Indian Maoist cultures developed at about the same time and use a common language. As far as martyrdom is concerned, the contents of the journal People's March, suggest a stronger focus on hierarchy among the Naxalites, with a great majority of tributes to martyrs dedicated to prominent leaders (and a number of them to Bhagat Singh...). They do not deal with the emotion created by martyrdom, but rather insist on the loss for the organization. Similarly, the journal does not include poetry or songs, contrary to the Nepalese ones. Some Indian customs, such as the shahid yatra (during which the martyr's ashes are sometimes scattered) and martyrs' columns, are not reported in Nepal. One main difference between the two contexts is that the Maoist party in Nepal developed as a strong organization covering the whole country, while the 'lack of regular communication between the various zones' is deplored by the CPI 
(Maoist) in India. The global nature of the Nepalese People's war led any victim of the government forces to be hailed as Maoist martyrs, while in the Indian context, the tendency instead is to consider only dead Maoists true martyrs (People's March, in its December 2007 issue, reports the death of Com. Rammehar 'martyred due to an attack of malaria' and of Com. Punna Rao, due to 'ill health').

8. On Mao's eulogy 'Serve the People', see Hung (2008).

9. Similarly, the Kashmiri jihadist groups in the 1990s 'had no monopoly on the term 'martyr' ( shahid), used by the Pakistani army and non-Islamist Kashmiri organizations alike. But they were the only ones who used it as a strategy to prepare young people to die' (Blom 2007: 72).

10. The passage in Nepali reads: 'We are a nice garden of 4 castes and 36 martyrs, how great!' The formula refers to the depiction of Nepal by its founding king, Prithvi Narayan Shah, as a garden of 4 castes and 36 classes (4 jat, 36 varna) (http://www.nepalnews.com). Another commentator proposes to rename Nepal, the Nation of Martyrs, while a third one objects: 'They are simply a newly discovered Ethnic Group, as such a new state should be added to the Federal structure for them, and it should be called Martyrwan'.

11. Nepalese Maoists had no doubt about their final victory, contrary to young Palestinians ( Larzillière 2003).

12. See Thapa Chal (2007): 'In your memory. My dear comrade Pavitra.../ Always at night I watch the sky / It seems to me that among the stars / One star is you / In it, I see your reflection / I see you, really you /...Those who die in the revolution are martyrs / They survive forever, even dead / Martyrs become stars in the sky / This is why I'm searching you among stars / Yes your material body is no more but / You show me the way'.

13. On the Maoist conception of war and its transformative effect, see Lecomte-Tilouine (2010).

14. Equal empowerment by weapons is a major Maoist theme: Prachanda's slogan was 'a gun for each citizen', at the September 11, 2009 meeting in Kathmandu.

15. Yet, their being designated as martyrs was contested. Thus in Dullu, people whispered during the ceremony addressed to a district committee member whose death had been accidental. And, in the same locality, a mass protest was launched when a man forcibly appointed as head of a ward in the Maoist People's government, was covered by a Maoist flag after being killed by the army. On these two incidents, see Lecomte-Tilouine (2008-2009).

16. See the poems 'Unhappiness is happiness' by Dev Sharma, or 'Dear Death' by Ganga Shrestha.

17. Interview, Jutpani PLA Camp, September 2009.

18. Dialectics also gave birth to a particular way of expression. Thus, when Prabhakar (2005), the western division commander, was asked by a journalist: 'Was the attack [on Pili] prepared long in advance?' he answered: 'We did not prepare it long in advance, though on the other hand, we did'.

19. See, for instance 'Raktabij' (Bloodseed), a poem by Sapana and Sacet (2007): 'We the Bloodseeds/Sprout of the revolution/ Grow of gunpowder and blood/ Grow amidst Blood'.

20. Islamic martyrs are also exempted from purification at their funerals; instead, they are buried with their bloody clothes as testimony, see Margalit (2003).

21. Three generations of ancestors are venerated by the Hindus, then the dead disappear forever.

22. All quotes in this section are from Ajayashakti (2009).

23. Li Hsin-T'ien (1972), Shan-shan-ti hung-hsing (Bright Red Star), Beijing: JMWH, 172 p.

24. Sarul was taken to a Maoist doctor, who extracted five other bullets from his body, then to a hospital in India. He was arrested at the border. His life in jail is another part of his epic, before he joined the PLA again.

25. A text signed by Ajayashakti (2003), using forceful statements, and a plethora of adjectives illustrates this contrast: 'blood-drinking murderers behave like drunken tigers... feudal supporters, like enraged, dogs go here and there biting people... immoral persons behave like Krishna and rape girls'. 
26. The expression is taken from Pasang (Caulagai 2007). It is true that accounts by Maoist war reporters can be very conformist and merely resemble propaganda. An extract of Om Sharma's report of the battle of Pili reads: 'A warrior fell. Another warrior seized his fallen rifle and went to the camp's barbed wire. No warrior worried about being wounded while fighting. Rather than worrying about their own bodies, they worried about the revolution. Even on the threshold of death, wounded warriors asked: 'What is happening in the battle?'... It's the rule that blood runs in war'. Among those who came as volunteers, there was no tangible terror: it was more a question of joy and enthusiasm. The volunteers said: 'The PLA is fighting against the enemy's camp. It is normal that we go and carry the wounded. In the revolution, one should help in whatever manner one can' (Janadesh, 14 (36), 2005).

27. Comrade Pradip, whose pen name is Balcan, 'Red Demon', was born into a poor Tamang family of Makvanpur and enrolled in the party in February 1999 at the age of 18. I interviewed him in September 2009 in the PLA camp of Jutpani.

28. Names are fictive.

29. For the brigade commissar Caulagai (2007: 50-1), 'If not written by a wounded or disabled heroic warrior this subject (i.e. war accounts) becomes imaginary'.

30. Sheridan (1968) retraces how, in China, the war's nameless heroes gave birth to more personal ones whose diaries, written in the first person, were published between 1963 and 1966, and then to a multitude of Red Guard heroes.

31. I wish to thank John Whelpton for his useful remarks.

\section{ABSTRACTS}

In Nepal, the Maoists' armed wing (PLA) developed as a collective of martyrs-to-be, whose example was disseminated as soon as they fell through tributes, poems and ceremonies. Its dynamic relied on self-sacrifice rather than any heroic prowess, and acquired a strong power of attraction in that it fundamentally asserts that anyone, whether illiterate, poor or of the lowest status, is of 'priceless' value, and can contribute to the project to change the order of things by putting their lives at stake. The People's War also brought about a wave of 'Living Martyrs', who survived the war and who are now busy recording their past experiences. They combine all the ingredients in terms of pathos and achievement to become historical figures and models for the future, while fallen immortals have already lost their individualities and play a collective and anonymous role.

\section{INDEX}

Keywords: fighters, Maoism, martyrdom, Nepal, People's War

\section{AUTHOR}

\section{MARIE LECOMTE-TILOUINE}

Senior Researcher, CNRS-Centre d'études himalayennes, Paris 